\title{
VALUE CATEGORIES AND THE CHOICE OF YOUTHS IN CONTEMPORARY TIMES
}

\begin{abstract}
The XXI century is marked by the dynamicity of social, political and economic changes. The period is characterized not only by variability, consumerism, but also by technological advancements. The level of technological maturity, ways of use of the internet, choice of means of communication, including ways of spending time online do have significant impacts on the quality of life of modern man. The glut of technological advancements and the overbearing dominance of online communication rather than true inter-personal relations may result in varied consequences. The on-going transformation of social life in complex societies derives from the fact that virtual relationships are overtaking local community lives. The world we live in is undergoing changes and we thus participate in this change. Although it does seem that the ability to adapt to changing environments is an elementary skill of man, the question of what changes this brings in areas of values does arise.

Values are such a multi-faceted phenomenon that descriptions of its varied aspects is possible. This can be attended to from view-points of philosophy, psychology, etnography, cultural antroplogy, sociology and economics. The article takes a closer look at the axiological level and issues of values from the philosophical perspective, not excluding elements of moral psychological. It presents short descriptions of varied concepts relating to values as well as their hierarchisation by Max Scheler. The characteristics and analysis of issues in the axiological sphere form the background to discussions on contemporary values. The summary of findings of analyses conducted among randomly selected adult students residing in Podkarpacie is provided. The objective of the study was an attempt to provide answers to questions concerning contemporary values. The interview method, based on a research questionnaire was applied for the study.
\end{abstract}

Keywords: axiology, values, Max Scheler, goodness, youth.

\section{INTRODUCTION}

The XXI century is not only about social, political and economic changes, but also a period when daily technology and cultural technology have become ideals that define our daily lives. Humans are changing along with their changing world with the ability to adapt to our environment becoming a basic skill of each of us, but the inherent question that emerges is how these changes impact on value systems. While survival was an objective and meeting basic needs as well as surviving served as keys in the past, we currently give form to everything and the most elementary activities take the form of art. We are becoming more refined, eating healthily, reading good books, drinking good wines and compulsorily undertakes fitness activities. The wealthier group is engaged in employing architects, designers, personal trainers and coaches. We boast of pictures from exotic restaurants (not necessarily delicious), how many kilometres covered (in new outfits) and levels of popular computer games achieved on social networks. We become aware, from

\footnotetext{
${ }^{1}$ Justyna Stecko PhD, Department of Humanities, Faculty of Management, Rzeszów University of Technology, ul. Poznańska 1, 35-084 Rzeszów, tel. 017 8651204, e-mail: jstecko@prz.edu.pl
} 
personalized adverts, of our subsequent needs, which again limits our time and freedom as we are intent on showing achievements in this area as well. The non-satisfaction of each of these needs yields frustration. It turns out, in effect, that what really limits us is excessiveness and not deficiency of choice. Of course this should be taken with a grain of salt, although this exaggeration is not entirely an imagined hyperbola. It, however, seem that we have lost the beauty of meetings, and the cinema as we are keen on accomplishing subsequent attractions and levels of achievements. A lay-in day is often treated as a wasted day. Our varied personality in today's unstable and changing world offers a means of survival. It does, however, have its negative consequences. We very often fail to find answers to the question of who we really are. The increasing lack of emotional engagement in inter-personal contacts and relationships is also observable. We do not desire and are not able to repair whatever that is breaking down as it no more constitute values to us. It is easier to change a friend or a partner for another than amend the relations. Heartless feelings facilitate continuous changes as too much involvement would result in trouble and negative emotions when parting ways ${ }^{2}$. Can stable values still find a place in such a world? Is XXI century an era of new humanism and if yes, what type? Do young people, in contemporary times, perceive any kind of higher values? The paper is an attempt to provide answers to some of these questions.

\section{CATEGORIES OF VALUES}

In making use of the value concept, one has in mind that which has for long been defined in history of philosophy as goodness, moral benefits, virtue and arete. Axiology, as a failed remedy for the crisis, emerged at the end of XIX century and as a value science examines their genesis, structure, hierarchy as well as their mechanism of impacting on other spheres of human activity. The scientific analysis of the essence of values from the perspective of philosophical reflections was undertaken by Rudolf Lotze. He postulated that ethical norms differ from natural ones in that they never lose their significance even when not achieved. It, thus mean they represent a specific goodness or something which has value. Nevertheless, it is how a given value is appreciated that prejudges the significance people attach to it.

One of the most popular and most cited philosophers, that provided an interesting hierarchy of values is Max Scheler. Metaphysics, according to Scheler, has similarly been used in reference to „knowledge of the reality as well as the theory of absolute values" 3 . We can, thus distinguish between the various spheres:

„1. Absolute sphere, consisting of what is real, valuable and sacred.

2. The Sphere of contemporary (Mitwelt), past and future world, i.e., the sphere of society and history, and the "others".

3. The sphere of external and internal world as well as its body and its environs.

4. The sphere of what is assumed to be ,alive".

5. The sphere of the world of the dead (Körpelwelt) or that which seem to us as dead",

One can, in reference to Scheler's typology, distinguish five, physical, life, sensory, social and ideal (pure) facts that do not possess their substantive equivalents. The order of

\footnotetext{
${ }^{2}$ http://www.neurobiopsychologia.pl/index.php/2014/06/08/jaki-jest-wspolczesny-czlowiek/

${ }^{3}$ M. Scheler, Problemy socjologii wiedzy, Warszwa 1990, s.135.

${ }^{4}$ Ibidem, s. 74-75.
} 
their absorption reflects the level of our moral development while the ability to sense them defines our personal being ${ }^{5}$. We experience feelings not necessarily because it is the outpouring of some needs, but rather they constitute the contents of our acts. We would have been robot-like if devoid of feelings. Access to values and their associate perception calls for the engagement of the personal self, which is not automatic. The Scheler's classification of values into four groups that aligns with the four levels of feelings (emotional, vitality, mental and spiritual - redemption) is most often applied in contemporary conceptualisation of values ${ }^{6}$. Scheler lists sensory, vitality, spiritual and religious values. The first of the aforementioned is goodness that is utilitarian in nature (an object) that may connote pleasure or pain. The next, usually assigned to man, are the advantages and disadvantages, including the strengths and weaknesses of the character. The spiritual values refer to the beauty and ugliness as well as the truth or its opposite. The last of the mentioned values refers to the religious aspect, whose implementation could be completely absorbing to man. Scheler did not, however, in his typology distinguish moral values as they are, in his belief directly related to the human being, which is attainable only in relation to other people. Hence meeting one's physiological needs is not a value not until it relates to the presence of another person and the initiation of empathy with them. Feelings determine the mode of existence of values in man, while love as a selfless feeling serves as a state of experience as well as a comparison of values.

The basis of human cognition, perception of values is his ability to empathize with a second person. Feelings that relate to our physicality are primary, but devoid of any intentional status and the presence of second person is not necessary to experience this feeling. The other feelings call for the participation of our consciousness and are thus of a higher order, intentional and can be equated with feelings of value. „Man is happy only when he loves and gives out, $[\ldots]$ it is better to give than receive. Love $[\ldots]$ on its own is an autonomous value, which on filling someone makes existence and life [...] rise higher and becomes more stable and richer. It is, therefore not about making people feeling the best, but rather that there is much love emanating between them"7. Man for Scheler is first and foremost ens amans (a loving being), and only later is he ens cogitas (a thinking being) as well as ens volens (a being that applies will-power). Love, according to Scheler is a basic axiological experience, directed at a value while its object can only be something which is a bearer of values.

Heidegger presents a somewhat different view on the issue of value. Heidegger within one year of Max Scheler's demise sarcastically comments the first volume of the biography of the German-speaker that contained a list of 661dissertations devoted to values 8 in his „Letter on Humanism” noting that: ,to stigmatize something as the indication (an attribute) of value deprives that which ought to be valued all the dignity. This can be understood thus: the estimation of something as valuable turns that which is valuable into a subject of human evaluation. [...] Similar thoughts on value is, here and elsewhere, the greatest imaginable blasphemy against existence"

\footnotetext{
${ }^{5}$ M. Scheler, Istota i formy sympatii, Warszawa 1986, s. 228-318.

${ }^{6}$ M. Scheler, Cierpienie, smierć, dalsze życie, Warszawa 1994, s. 8.

${ }^{7}$ M. Scheler, Resentyment a moralność, Warzawa 1977, s. 101.

${ }^{8}$ M. Heidegger, Wprowadzenie do metafizyki, Warszawa 2000, s. 182.

${ }^{9}$ M. Heidegger, List o humanizmie, Warszawa 1977, s 27.
} 
What then is the world of values? It is according to Maria Gołaszewska not a zero-one approach with the choices not always being obvious. We, on daily basis encounter greater or lesser categories of goodness, including its analogical greater and lesser evil. There exists, in her opinion, „[...] a prevalent conviction that there exist a lesser and greater evil and that some human behaviours and states of things can be ranked regarding the time of their interactions with a specific value, be it negative of positive" ${ }^{\prime 10}$.,»The chessboard « of values is a system of possibilities that make them seem close to their primary properties. This is an encounter of polarity, i.e, positive - negative values (pendant for both black and white person); where there exists no suggestion that any of them exercises special "privileges" within the system, but they are opposed to each other. There also exist a gradation of values from the »more important«, higher through those whose functions in the anthroposphere are limited up to those »one-dimensional« values, having small-scale impacts. The most significant here, however, is the system of movements, the system of possibilities of mutual interactions between values as well as with man, who is ranked among the highest values. The rules of a chess game are precise, while similarly allowing in theory finite movements which are virtually incalculable in numbers and combinations until the attainment of a situation, where there no more exist a next move or next axiological possibility" "What therefore, are the said values that dictate our choices and actions? Do they possess an objective character of existence or rather subjective beliefs? Literature abound with numerous disputes between followers of axiological subjectivity and those of objectivity or relativism. Values, in the opinion of the former, exist in the experiences of the entity (object), with their opponents arguing that value implies the subject, but for the followers of relativism they are a form of relationship between the subject and the object. The next dispute in respect of values concerns their durability. Whilst values, according to the relativists, are dependent on historical, social or economic conditions they, in the opinion of absolutism, remain unchanged, and are independent of the dynamically evolving conditions thus serving as foundations to which we can always appeal. Tatarkiewicz is of the opinion that defining value is difficult, if not impossible. That, which very often looks like a definition of value is nothing more than the mere replacement of a word with another or a discussion.

The terms value, axiology and axiological are not only currently in wide circulation, but are also very popular although they say nothing about values except on their subjective preferences. The discriptive criteria of values is varied as value is at a time deemed an end in itself but at another as a criterion for the choice of objectives or motives of actions. There are also approaches that indicate similarity between the concepts of norms and values, but they are most commonly treated as the subjective evaluation of the beliefs of individuals.

The value of modern man as a term defines that which is valuable, which often can refer to a desired goal. Values are, according to Tomaszewski, often implemented so that the "individual could achieve the fullness of its existence, physical and physiological well.being. Values becomes for a man that which is needed for his life, physical and mental comfort, active development, the sense of being needed and happy. It is also everything that defines the human identity and its place in the surrounding world"12

\footnotetext{
${ }^{10}$ M. Gołaszewska, Fascynacja złem, Warszawa-Kraków 1994, s. 43.

${ }^{11}$ Ibidem, s. 43.

${ }^{12}$ J. E. Karney, Psychopedagogika pracy, Warszawa 2007, s. 41.
} 


\section{CONTEMPORARY VALUES}

The question that arises is what young people understand through the concept of „value”. The study was conducted amongst randomly selected adult learners across secondary schools in Podkarpacie Province ${ }^{13}$. The study used an interview method, based on a research questionnaire. The first interview was conducted in 2009, while subsequent ones were in 2012 and 2015. The respondents were asked to attempt to define the value concept and then choose 10 most significant for them values from a catalogue of 50 . Over $40 \%$ of them had difficulties defining the concept. They most often, however, indicated what is valuable and that which might serve as the target of their actions. Majority also opined that the concepts are subjective and dependent not only on cultural spheres, but also on the stage of life we live in. Interestingly, the value of love for the young was ranked highest in all interviews, while the other value failed to enjoy this regularity in rankings. The choice of faith as one of the most important values in 2009 seemed interesting although it never surfaced at any time, instead beauty as a value was placed at a high 6th position. The year 2015 brought about further changes. Categories such as truth, justice and health were replaced by others like trust, self-realization and safety which has gained in significance recently. Today's young people are mostly seeking friendship, love and security, but also indicate that material affluence and family are equally significant aspects of their lives. Only beauty and goodness of the triads survived, but were supplemented by the need for self-realization and the search for wisdom. Truth turned out to be a less desirable value in 2015 .

Table 1. A survey of values

\begin{tabular}{|c|c|c|c|}
\hline RANKING & $\mathbf{2 0 1 5}$ & $\mathbf{2 0 1 2}$ & 2009 \\
\hline & CHOSEN VALUE & CHOSEN VALUE & CHOSEN VALUE \\
\hline 1 & FRIENDSHIP & LOVE & FAMILY \\
\hline 2 & LOVE & FRIENDSHIP & LOVE \\
\hline 3 & SAFETY & JUSTICE & FRIENDSHIP \\
\hline 4 & WELL-BEING & HEALTH & WELL-BEING \\
\hline 5 & FAMILY & FAMILY & JUSTICE \\
\hline 6 & BEAUTY & BEAUTY & GOODNESS \\
\hline 7 & GOODNESS & GOODNESS & TRUTH \\
\hline 8 & SELF- & WELL-BEING & HEALTH \\
\hline 9 & REALIZATION & & WISDOM \\
\hline 10 & WISDOM & WISDOM & FAITH \\
\hline
\end{tabular}

Source: : own elaboration ${ }^{14}$.

\section{SUMMARY}

Modern analyses on values indicate the existence of numerous changes in their hierarchy, both in societal and individual life. Lots of publications have highlighted these changes or even crisis in respect of values. This, for some, means parting with traditional

\footnotetext{
${ }^{13}$ J. Stecko., Młodzi wobec aksjologicznych wyzwań swoich czasów, [w:] Edukacyjne zagrożenia i wyzwania młodego pokolenia, pod red. A. Czajkowska, W. Otwinowski, Poznań 2009, s. 348-357

${ }^{14}$ Results presented at the conference "Education of the 21st century"Szczyrk 2015.
} 
values, while for others the issue in question is about doubting the ideal. Do we have to bemoan this by trying to identify the crisis or downfalls in the world of values? Do we have to be so critical of the situation? It does seem that the youth perceive values and are capable of making choices. Majority of the respondents made effective attempts to define the term "value". Surprising though is the fact that young people do not seek values that are associated with patriotism, and faith in the transcendent dimension, while the category of truth is foreign to them. The youth are more often interested in self-realisation, including life's comfort in love and friendship. Nonetheless, the key conclusion of this article is that people just at the onset of their adult lives are capable of perceiving values and making choices. This, perhaps, may serve as the only premise to which we can appeal in discussions with the generation that have just become participants in the social dialogue.

\section{KATEGORIA WARTOŚCI A WYBORY LUDZI MLODYCH W CZASACH} WSPÓLCZESNYCH

XXI wiek to dynamiczne zmiany społeczne, polityczne i gospodarcze. Znakiem naszych czasów jest nie tylko zmienność, konsumpcjonizm ale także zaawansowane technologie. Poziom dojrzałości technologicznej, sposoby wykorzystywania internetu, dobór środków komunikacji oraz formy spędzania czasu w sieci mają znaczący wpływ na jakość życia współczesnego człowieka. Nasycenie zaawansowaną technologią oraz zdecydowana przewaga komunikacji w sieci aniżeli prawdziwych relacji międzyludzkich może mieć różne konsekwencje. Transformacja życia towarzyskiego w złożonych społeczeństwach polega na tym, że wirtualne relacje zastępują społeczności lokalne. Zmienia się świat, w którym żyjemy, więc zmieniamy się także my sami. Wydaje się, że adaptacja do otaczającego środowiska to jedna $\mathrm{z}$ podstawowych umiejętności każdego $\mathrm{z}$ nas, pojawia się jednak pytanie, jakie niesie to ze sobą zmiany w świecie wartości?

Wartości są tak wielopostaciowym zjawiskiem, że można ukazywać różne ich aspekty. Zajmować się nimi można $\mathrm{z}$ pozycji filozofa, psychologa, etnografa, antropologa kulturowego, socjologa czy ekonomisty. Artykuł przybliża płaszczyznę aksjologii i zagdnienie wartości w ujęciu filozoficznych z elementami psychologii moralności. Krótko opisuje różne ujęcia wobec zagadnienia wartości oraz ich hierarchię w ujęciu Maxa Schelera. Charakterystyka i analiza zagadnia płaszczyzny aksjologicznej są them do rozważań na temat współczesnych wartości. Podsumowaniem są wyniki analiz przeprowadzonych wśród losowo wybranych pełnoletnich uczniów zamieszkałych na terenie województwa podkarpackiego. Celem badań była próba odpowiedzi na pytanie dotyczące współczesnych wartości. W badaniach wykorzystano metodę wywiadu, opartą o kwestionariusz badawczy.

Słowa kluczowe: aksjologia, wartości, Max Scheler, dobro, ludzie młodzi.

\section{BIBLIOGRAFIA}

[1] Gołaszewska M., Fascynacja złem, Warszawa-Kraków 1994.

[2] Heidegger M., List o humanizmie, Warszawa 1977.

[3] Heidegger M., Wprowadzenie do metafizyki, Warszawa 2000.

[4] Karney J.E., Psychopedagogika pracy, Warszawa 2007.

[5] Mellibruda J., Wewnętrzny proces wartościowania: http://www.psychologia.edu.pl/dziupla-jurka/teksty/1368-wewnetrznyproces-wartosciowania.html 
[6] Stecko J., Młodzi wobec aksjologicznych wyzwań swoich czasów, [w:] Edukacyjne zagrożenia i wyzwania młodego pokolenia, pod red. A. Czajkowska, W. Otwinowski, Poznań 2009, s. 348-357

[7] Scheler M., Problemy socjologii wiedzy, Warszwa 1990.

[8] Scheler M., Istota i formy sympatii, Warszawa 1986.

[9] Scheler M., Cierpienie, smierć, dalsze życie, Warszawa 1994.

[10] Scheler M., Resentyment a moralność, Warzawa 1977.

DOI:10.7862/rz.2015.hss.26

Przesłano do redakcji: styczeń 2015

Przyjęto do druku: czerwiec 2015 